Fall 1997

\title{
Toward a Stylistic Chronology of Johan Helmich Roman's Symphonies
}

Bertil Van Boer

Western Washington University, bertil.vanboer@wwu.edu

Follow this and additional works at: https://cedar.wwu.edu/music_facpubs

Part of the Music Commons

\section{Recommended Citation}

Van Boer, Bertil, "Toward a Stylistic Chronology of Johan Helmich Roman's Symphonies" (1997). Music Faculty and Staff Publications. 1 .

https://cedar.wwu.edu/music_facpubs/1 
Toward a Stylistic Chronology of Johan Helmich Roman's Symphonies Author(s): Bertil van Boer

Source: The Journal of Musicology, Vol. 15, No. 4 (Autumn, 1997), pp. 471-500

Published by: University of California Press

Stable URL: http://www.jstor.org/stable/764004

Accessed: $16 / 10 / 201412: 53$

Your use of the JSTOR archive indicates your acceptance of the Terms \& Conditions of Use, available at http://www.jstor.org/page/info/about/policies/terms.jsp

JSTOR is a not-for-profit service that helps scholars, researchers, and students discover, use, and build upon a wide range of content in a trusted digital archive. We use information technology and tools to increase productivity and facilitate new forms of scholarship. For more information about JSTOR, please contact support@ jstor.org. 


\section{Toward a Stylistic Chronology of Johan Helmich Roman's Symphonies}

BERTIL VAN BOER

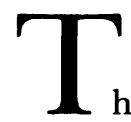

he determination of a chronological order in the works of a composer is a central issue in any understanding of the music since stylistic development over time can show how one's musical language is formed and progresses. Moreover, it can demonstrate how the influences of the various styles with which a composer comes into contact shape the music. In the case of Johan Helmich Roman (1694-1758), the creation of an individual style over time is particularly important, for the span of his creative life was spread over the transition from the High Baroque style of well-known composers, such as George Frederick Handel and Georg Philipp Telemann, to the more forward-looking triadic music of the galant or early Empfindsamkeit composers of the middle of the century. The latter include flautist Johann Joachim Quantz, Johann Gottlieb and Carl Heinrich Graun, all of whom were resident in Berlin, the home of Sweden's new crown princess, Lovisa Ulrika. Indeed, the variety of musical development during his lifetime can be summarized in a chronological comparison: Roman, who predeceased his spiritual mentor Handel by one year, outlived that harbinger of the so-called Classical style, Johann Stamitz of Mannheim, likewise by a single year. Thus it was theoretically possible for him to have been cognizant of a wide range of musical styles, from the contrapuntal Fortspinnung of the early Baroque that he learned as a youth in Britain to the short, emotional, Italianate music of the Empfindsamkeit to the lyrical, instrumentally-powerful, yet often cliché-ridden central European style of the Mannheim composers. In short, by the time of his death, 
Roman could have known, or at least have been aware, of a plethora of musical styles ranging from the anachronistic to the modern. It would therefore be logical to suggest that Roman's music might well be a mirror of the development of those styles, which would be manifested in a genre, such as the symphony, allowing for a tentative chronology of these works to be established on stylistic grounds.

The chronology of Roman's symphonies is problematic at present: apart from one work, none of the rest of the twenty authentic works has been dated any more specifically than a timespan ranging from $1737-175^{2 .}{ }^{1}$ Only the Symphony in G major (BeRI ${ }^{15}$ ) contains a note-"Fogelvik, Aug. 2, 1746"-showing when it was written. In addition, the Symphony in F major (BeRI 10) can be dated with some accuracy; according to a note on the basso part, it was designated as part of the "Printz Gustafs Musique," implying that it was specially composed for the birth of Gustav III on 24 January 1746 . Bengtsson notes that his timespan was formulated based upon a terminus ante quem non of 1737 , when Roman returned from his second journey abroad, and a terminus post quem non of 1752, when the composer appears to have retired and left Stockholm, turning his compositional energies toward the writing of sacred music. ${ }^{2}$ This is an expansion of a more limited period postulated by Stig Walin, who noted: "The majority of Roman's symphonies were likely composed during the period when he regularly took part in the musical life of Stockholm, i.e., before 1745 when he left Stockholm for various reasons to dwell in his home Haraldsmåla in Småland." 3 While this does present a

${ }^{1}$ For the literature on the symphonies of Roman, see Ingmar Bengtsson, $J$. $H$. Roman och hans instrumentalmusik (Uppsala, 1955); Stig Walin, Beiträge zur Geschichte der schwedischen Sinfonik (Stockholm, 1941); Patrik Vretblad, Johan Helmich Roman 16941758: Svenska muskens fader, 2 vols. (Stockholm, 1914); The Symphony in Sweden Part I; Johan Helmich Roman, Six Symphonies, ed. by Ingmar Bengtsson, The Symphony 1720 1840 Vol. F II (New York, 1982); Ingmar Bengtsson, "Instrumentale Gattungen im Schmeltztiegel: Zur Orchestermusik von Johan Helmich Roman (1694-1758)," in Gattung und Werk in der Musigeschichte Norddeutschlands und Skandinaviens, ed. by Friedhelm Krummacher and Heinrich Schwab (Kassel, 1982), 97-106; Lennart Hedwall, Den svenska symfonin (Stockholm, 1983); and Musiken i Sverige, Vol. 2, ed. by Anna Johnson (Stockholm, 1993). Additional articles on the subject of individual works and authenticity can be found quoted infra the sources listed above and elsewhere in this article.

${ }^{2}$ Bengtsson, Roman, Six Symphonies, xviii. See also Bengtsson, Roman, 407-08. In the latter, the author postulates a more narrow timespan of a decade, 1737-47, based for the most part upon stylistic and the meager source criteria. Hedwall (Symfonin, 24) follows Bengtsson's starting date, but leaves open the question of terminus ante quem: "De flesta av dem tillkom efter 1735."

3 Walin, Schwedischen Sinfonik, 340 Note 3: "Die meisten Sinfonien Romans dürften wohl in der Zeit komponiert worden sein, in der er an dem Stockholmer Musikleben rege [sic] teilnahm, also vor dem Jahre ${ }_{1745}$, in dem er aus verschiedenen Gründen Stockholm verliess, um sich auf seinem Gut Haraldsmåla in Småland niederzulassen." Bengtsson (Roman, 408) notes drily that Walin's chronology, ca. 1737-45, makes exception for Roman's only securely dated work. 
limited chronological range, all scholars have cautioned against accepting it as definitive. Bengtsson has noted that the watermarks of the surviving autographs are inconclusive, valid for both decades, while both he and Walin are extremely tentative in formulating a chronological order based upon subjective stylistic criteria.4 The result is simply a postulation of "periods" of compositional activity within the genre: the first (ca. 1730-37) was when Roman wrote two-movement overtures similar to both the Sinfonia da chiesa and French overture, the second (ca. 1737-45, a so-called "Intermediate Period [Mellanperiod]") when there is some indication of Baroque concerto-ritornello form or structure and multi-movement suite-like works, and the final (running the stylistic gamut ca. 1737-52) when all of the rest were written.

This overlapping periodization of the symphonies still begs the questions of order of composition, of stylistic development as Roman himself became aware of the latest trends in symphonic composition on the Continent, and of circumstances through which he might have been inspired or commissioned to write works in this genre. While there may not be enough evidence to date each of the authentic symphonies accurately, a view of several additional factors-revisiting the known chronology, the performance opportunities, the comparative development of the symphony elsewhere, internal stylistic evidence, and personnel available to perform the works - can be useful in narrowing the timespan, allowing a reassessment of the chronology.

Biographical details of Roman's life are closely intertwined with his compositions, and in that light the periods within which he wrote symphonies need to be re-examined. The question of when Roman began to write symphonic works depends upon two facts: first, how one defines a "symphony" and second, what occasions or performance possibilities existed, both during his career as one of the leading musical figures in Stockholm and following his retirement.

The genre itself was relatively new during the first half of the century; although Johann Mattheson first described it in his $\mathrm{Neu}$ eröffnete Orchester of 1713 as "compositions as are solely performed on instruments," his and other descriptions almost exclusively refer to its use as an introduction for vocal works, either in the church or at the theatre. 5 The symphony appears not to have existed as an independent genre, although a suite-like version of the Sinfonia da

4 Bengtsson, Roman, Six Symphonies, xx; idem., Roman, 407-og; idem., "Instrumentale Gattungen," 100-01; Walin, Schwedischen Sinfonik, 340-41. Bengtsson concludes (Roman, Six Symphonies, xviii): "At the present time it is impossible to improve upon this chronology." Johnson (Musiken i Sverige, 47) concurs with this assessment.

${ }_{5}^{5}$ Johann Mattheson, Das neu-eröffnete Orchester (Hamburg, 1713), 171; see also the same author's Kern melodischer Wissenschaft (Hamburg, 1737), 125. 
chiesa had existed since the middle of the previous century. ${ }^{6}$ What did exist were generically lumped under rubrics such as (French) Ouverture, Suite, Sonata, or Concerto (grosso); these works usually consisted of a series of stylized dance movements prefaced by a two-section movement comprising a slow introduction with dotted rhythms followed by a fugue. The latter, commonly written for Northern European serious opera, was occasionally performed separately from the dramatic work as a concert piece.

During the first part of Roman's life, especially during his brief career in England as a professional musician and afterwards up to his second journey abroad in 1735 , this was essentially the only type of "symphony" with which he would have been familiar, and datable works from this period clearly show his dependence upon these Baroque models with their extensive use of Fortspinnung, characteristic counterpoint, clear Baroque form and structures. Although there is little evidence of concentrated personal tutelage by composers such as Johann Pepusch and George Frederick Handel during his years in England-neither normally accepted students and were in any case far too busy with their professional careers to tutor younger musicians 7 -it is clear that Roman learned a great deal about the style and form of their music through actual performances in which he participated. When he returned to Sweden in 1721 as ViceKapellmästare, he was well-versed enough in the instrumental forms of the time that he was able to apply his knowledge to compositions of an occasional sort.

The works composed during this period, beginning with a Birthday Overture for Frederick I in 1725 , all reflect this Baroque dramatic style, even though Roman himself "had no liking for theatrical and comic music," as a student of his, Johan Miklin, once noted. ${ }^{8}$ For the most part, these are all associated with some sort of festive occasional music; examples include the 1727 Cantata zu einer Taffel-Musik, the

6 Examples of this include a Sinfonia a quattro published by Giovanni Maria Bononcini $(1642-78)$ in 1671 in Bologna. His son, Giovanni Bononcini (1670-1747), who was Handel's rival in London and certainly known to Roman, published as some of his earliest works a set of Sinfonias for between five and eight instruments in Bologna in $1_{5}$, followed two years later by a set of Sinfonias da chiesa (Op. 5). All of these, however, emulate either the four-movement sonata da chiesa or the traditional $\mathrm{Ba}$ roque suites.

7 See Abraham Sahlstedt, Äreminne öfwer Hofintendenten Kongl. Capellmästaren Johan Helmich Roman (Stockholm, 1767), 16-17. Sahlstedt postulates that Roman was employed by the Duke of Newcastle as a Gentleman. According to a recentlydiscovered payroll list from the Royal Academy of Music from 1719, Roman is listed as one of the least paid members of that group. See Johnson, Musiken $i$ Sverige, 28-29; Bengtsson, Roman, 21-22.

8 See Bengtsson, Roman, Six Symphonies, xvii. 
overture to a birthday cantata for Queen Ulrika Eleonora Freudige Bewillkommung of 1726 , and an introduction to the so-called BröllopsMusik, a cantata for the marriage of Otto von Schwerin and Hedvig Charlotta Tessin in 1729. All of these are scored for strings and continuo, with an occasional pair of oboes (and bassoon), which, in true Handelian fashion, reinforce the string lines through doubling and provide some contrast. There are also several works which carry the designation "Sinfonia" or "Overtura da chiesa," likewise in twomovement overture form. These works (BeRI 37-38, 42-43) might have been appropriate in a Catholic country where the Sinfonia da chiesa form was commonplace, but they had no purpose within the rather strict Lutheran services of the time, although there is a piece of evidence that suggests at least one may have been performed in the Tyska Kyrka on the third Sunday after Pentecost in $1724 .{ }^{9}$ Another opportunity, however, presented itself; in 1731 Roman inaugurated a series of public concerts at the Riddarhus during Lent and Easter, possibly in imitation of both the Castle concerts established in London in 1715 and the Concerts Spirituels founded in Paris in $1725 .^{10}$

Whatever model they were following, it was Roman's intention that they eventually develop into a seasonal series that both showed off the Hovkapell at its best and presented a wide variety of music for the public's pleasure. The composer himself stated this intention to "attempt to bring music such a position that, in terms of solemn music, it could be used in answer to the objections that were done to honor our nation." ${ }_{11}$ For the first several years, he presented annual Lenten or Paschal concerts that featured sacred music, although beginning in 1733 he began to expand the musical spectrum by offering first performances of some of Handel's anthems, and subsequently during Carnival of 1734 a performance of a Handelian "Pastoral eller ett Herda-Qwäde," likely the serenata Acis and Galatea, both in Swedish translation. ${ }^{12}$ But during Lent, he returned to sacred works, even

9 Listed in Patrik Vredblad, Konsertlivet $i$ Stockholm under 1700-talet (Stockholm, 1918), 137. See also Vretblad, Roman, 28.

10 See William Weber, "London: A City of Unrivaled Riches," in Neal Zaslaw, ed., The Classical Era (Englewood Cliffs, NJ, 1989), 307-08 and Constant Pierre, Histoire des Concerts Spirituels (Paris, 1975), 15; Vretblad, Konsertlivet, 22-23; Johnson, Musiken $i$ Sverige, II, 42-43. In London, the public concerts were held more or less year round at the Castle Tavern, which boasted a small stage, while in Paris they were given mainly during Lent at the Swiss salon in the Palais des Tuileries. Roman possibly participated as a freelance musician in the former, although he may have heard of the Parisian series through his patrons; the Swedish court was extremely francophilic and the latest trends were always quick to reach Sweden.

1 Johan Helmich Roman, Preface to En Swensk Drama by A. N. Leenberg (Stockholm, 1734): "[att] söka bringa Musiquen i det stånd, hwarigenom den wid solenne tilfällen må behörigen swara emot de anstalter som då giöras för vår Nations heder.”

12 See Vretblad, Konsertlivet, 139-40; Johnson, Musiken i Sverige, II:43. See also Alan Swanson and Bertil van Boer, "A Swedish Reinterpretation of Handel's Acis and 
conducting the premiere of Handel's new oratorio Esther, written only three years earlier. ${ }^{13}$ In any case, it would have been entirely appropriate for Roman to have inserted a Sinfonia da chiesa into the concerts, particularly as an introduction to the Brockes Passion, which has only a brief and rudimentary overture. This would account for both the free-standing overtures and the various overture arrangements (BeRI 40 in $\mathrm{F}$ major arranged from Handel's in addition to other works and BeRI 41 in B-flat major from Act II of Handel's opera seria Scipione of 1726).

If one accepts this suggestion, that the performance opportunities with the new Riddarhuskonserter combined with Roman's affinity for Handel during this period in his life provided motive and opportunity for the composition of Baroque overtures, then it is possible to suggest a tentative chronology. If instrumental works were used to introduce the Passion, the first two of the Riddarhuskonserter from 1731 and 1732 may have included Roman's arrangements of music by Handel as noted above. Their apparent success would then have allowed Roman to consider writing his own, based both upon the Handel French overtures and his own experience writing introductions for the various cantatas and other works during the preceding decade. The overtures in C major (BeRI 37) and G major (BeRI 38) would therefore date from his last seasons before his second grand tour, 1733 and 1734 respectively. Their high Baroque style and form, coupled with the occasion presented by the concert series, gives both motive and opportunity, although it is impossible to say which came first, since there are for all apparent purposes no stylistic differences between the two works. Thus Roman's first period of activity can be summarized as a concentration upon more or less traditional instrumental forms such as the French overture; the suggested chronology is listed in Table One. ${ }^{14}$

In 1735 Roman apparently received permission to travel abroad again, this time both to update his own skills and to become familiar

Galatea," Scandinavian Studies LXV (1993), 33-34. Where Roman came up with a score to Acis cannot be determined, since it was not published until 1743. Its appearance in Stockholm, however, allows at least the speculation that Roman himself knew of the work and its performance at the estate of Lord Chandos in 1718; it is possible that he even participated in the premiere as a member of the orchestra, though there is no evidence that has survived.

13 The fact that this work appears, in Swedish translation by Leenberg, only a short time after its premiere in London may suggest that Roman was in direct correspondence with someone in England, possibly even Handel.

${ }^{14}$ See Bengtsson, "Instrumentale Gattungen," 1oo. Bengtsson also concurs with this early dating, noting: "Offensichtlich gehören die meisten französischen Ouvertüren einer relativ frühen Periode an, etwa der Phase von den zwanziger Jahren bis $1735 . "$ 
TABLE 1

Symphonic Works by Johan Helmich Roman

Baroque Period (1721-35)

\begin{tabular}{|c|c|c|c|}
\hline Work & Bengtsson No. & Date & Purpose \\
\hline $\begin{array}{l}\text { 1. Overture in } \mathrm{F} \\
\text { major Festa musicale }\end{array}$ & BeRI 32 & 1725 & Fredrick I's Birthday \\
\hline $\begin{array}{l}\text { 2. Overture in D } \\
\text { major Freudige } \\
\text { Bewillkommung }\end{array}$ & BeRI 33 & 1726 & Ulrika Eleonora's Birthday \\
\hline $\begin{array}{l}\text { 3. Overture in D } \\
\text { major Taffel-Musik } \\
\text { Cantata }\end{array}$ & BeRI 34 & 1727 & New Year's Concert \\
\hline $\begin{array}{l}\text { 4. Overture in } \mathrm{F} \\
\text { major }\end{array}$ & BeRI 35 & 1731 & $\begin{array}{l}\text { Introduction to a cantata } \\
\text { celebrating Frederick I's } \\
\text { return from Germany }\end{array}$ \\
\hline $\begin{array}{l}\text { 5. Overture in } \mathrm{C} \\
\text { major }\end{array}$ & BeRI 37 & 1733 & Free-standing overture \\
\hline $\begin{array}{l}\text { 6. Overture in } \mathrm{G} \\
\text { major }\end{array}$ & BeRI $3^{8}$ & 1734 & Free-standing overture \\
\hline
\end{tabular}

with the latest trends on the Continent. It is evident from Sahlstedt's description of this grand tour that the composer not only was able to renew his old acquaintance both with Handel and Geminiani, he was also able to meet a number of composers new to him in Italy, the ultimate goal of his travels. ${ }^{15}$ Here he no doubt came into contact with the leading proponents of the new, more triadic galant style of opera seria, such as Sammartini, Porpora, Hasse, Vinci, and Leo. He became increasingly interested in the new style of instrumental music that was less contrapuntal, homophonic, and filled with melodic contrasts. Vretblad notes that he himself wrote several minuets (possibly among BeRI 261-275) for the Carnival season at the Palazzo Corsini, which the Swedish minister Nils Bielke remembered as being received with approbation. ${ }^{16}$ Here he also might have been aware of another of the predecessors of the symphony, the ripieno concerto, which was fairly popular in central Italy about this time. ${ }^{17}$

15 Sahlstedt, Äreminne, 17-18; see also Bengtsson, Roman, 35-38.

${ }_{16}$ Vretblad, Roman, 149; Bengtsson, Roman, 36.

${ }_{17}$ See Eugene Wolf, Antecedents of the Symphony: The Ripieno Concerto, The Symphony 1720-1840 Vol. A 1 (New York, 1983), xvi-xvii. 
Among his goals for this journey was the collection of music for the Swedish Hovkapell, and receipts of the time abroad bear witness to an extensive activity in this area. ${ }^{8}$ Since he was Kapellmästare, it is unlikely that he simply acted as a purchasing agent, and indeed made an extensive study of the material obtained. This would have increased his awareness that the newer galant style was rapidly replacing the older Baroque, forcing Roman, like his colleague Georg Philipp Telemann in Hamburg, to realize that he either had to adapt or become an anachronism in his own lifetime. Like Telemann, he apparently chose the former, which would explain Sahlstedt's assessment of this journey: "Our [Mr.] Roman travelled abroad as a great musician and returned home even greater; he had with him a collection of the most marvellous works and was now in the position of fulfilling his place of honor in the Swedish orchestra." 19

At this time, however, the symphony had not yet coalesced into its modern form. To be sure, Roman no doubt heard works that prefaced opera or other dramatic works that were akin to the modern Sinfonia, but there is little evidence that the genre existed as more than an occasional independent instrumental work. But multimovement works, entitled or sometimes subtitled suites or partitas, did exist, and there is some indication that these, along with the ripieno concerto, were in the process of change from stylized Baroque dance movements to more independently-conceived movements in ritornello or binary forms. This change was described in 1774 by J. A. P. Schulz, who remarked:

[The symphony is] a piece of instrumental music for many voices that is used in place of the now obsolete overture.... [The] lighter form of the symphony originally consisted of one or more contrapuntal pieces alternating with dance pieces of various types, which was generally called a 'partita' ... but soon one became tired of dance pieces without dancing, and finally settled for one or two fugal [e.g., contrapuntal] or non-fugal allegros that alternated with a slower andante or largo. This genre was called 'symphony' and was introduced in a chamber form..$^{20}$

${ }^{18}$ See Bengtsson, Roman, 35-36. Bengtsson specifically mentions receipts for the purchase of music from London, Dresden, and throughout Italy.

19 Sahlstedt, Roman, 19: "Wår Roman reste ut såsom stor Musicus, och kom större hem igen; han hade med sig en samling af de härligaste Musicalier, och war nu i stånd at upfylla sit äreställe i den Swenska Orchestren." Sahlstedt goes on to say that his secondary task during this trip was as an aware observer ("upmärksam åskådare") of noteworthy things in other countries. Although this primarily refers to a larger context-Roman left an extensive description of Rome in manuscript -it can also apply to his observations of music and the changing musical styles, since this was his profession.

${ }^{20}$ [J. A. P. Schulz], "Symphonie," in Johann Georg Sulzer, Allgemeine Theorie der schönen Künste, 5 vols. (Leipzig, 1771-74), II, 1121 . Translation from Neal Zaslaw, 
The pertinent facts of this historical description with respect to Roman and his second European journey lie in the statements that the earlier instrumental genre, the overture-by which is presumably meant the two-movement French overture-was considered oldfashioned, that the traditional Baroque suite, comprised of alternating fast-slow stylized dances, was regarded as no longer viable, and that a new genre consisting of a series of freely-composed movements was introduced with reduced chamber orchestration, meaning strings a3 or $a 4$. Although Schulz does not specify the period, early symphonic works by Sammartini and others from the late 1730 s clearly point to this time as the transition, and Roman's second tour took him to the center of where these changes were occurring. But, as an independent genre, the symphony still did not yet exist, and models produced in Italy and elsewhere continued to have a variety of names attached to them; partita, suite, Sinfonia, sonata, and overture. ${ }^{21}$ For example, on 7 January $173^{8}$ Antonio Vivaldi directed a seminal concert in Amsterdam, in which numerous works of this nascent genre were premiered, including those by Vivaldi himself, fellow-Swede Johan Agrell, who was resident in Germany, Sammartini, and others. ${ }^{22}$ Although Vivaldi's program calls them universally "Sinfonias," printed and manuscript sources of several of the works done about $174^{\circ}$ still list them either as suites, concertos, or sonatas, indicating that a universal nomenclature of this new genre was not yet accepted.23 Further, this also implies that the genre itself had not yet solidified, as indicated in Schulz's historical overview.

It is doubtful that Roman composed any symphonies during his tour; there were few opportunities, and his purpose for the trip was as an observer rather than as a composer. There are only two sorts of works that date from the two years spent abroad, both written apparently for specific occasions, the aforementioned minuets and a sonata.

Mozart's Symphonies (Oxford, 1989), 74 and Bathia Churgin, "The Symphony as Described by J. A. P. Schulz (1774): A Commentary and Translation," Current Musicology XXIX (1980), 7-16.

${ }_{21}$ See Walin, Schwedischen Sinfonik, 321 . Walin then proceeds to analyze the Roman symphonies in the light of this uncertain and unstable nomenclature, relying more on strict formal structures to establish a chronological order. His analyses $(321-40)$ are thus problematic, considering the parallel development of the symphony as an emergent genre and Roman's own apparent desire to move with the times.

${ }_{22}$ Jeanette Morgenroth Scheerin, Agrell, Five Symphonies, The Symphony 17201840 Vol. C 1 (New York, 1983), xxx; Newell Jenkins and Bathia Churgin, Thematic Catalogue of the Works of Giovanni Battista Sammartini (Cambridge, MA, 1976), 6, 91-92; Marc Pincherle, Antonio Vivaldi et la musique instrumentale (Paris, 1948), I, 24-25.

${ }_{23}$ Jenkins, Sammartini, 92. The Sammartini work performed at the concert, the Symphony in B-flat major (JC 65), was collected under the title Sonata in a group purportedly to have dated from that performance. Sources do not describe it as a symphony until a decade later. Agrell's work is, however, entitled separately Sinfonia, although it is technically listed as Sonata II in the collection. 
But when he returned to Stockholm in the summer of 1737 , he was certainly aware of both the incipient galant style and the developing genre. For the next several years, $173^{8-44}$, Roman appears to have continued with his traditional Lenten and pre-Lenten public concerts, which consisted of mostly sacred works. He also continued with his collection of music; additional packets of music arrived from London in 1736 and 1743 , the latter arranged by Swedish minister C. M. Wasenberg, and in $174^{2}$ Agrell sent a series of works to Roman from Kassel, possibly including some of his earliest symphonies. ${ }^{24}$

During this transitional time, it is likely that Roman experimented with the developing symphony, taking advantage of this opportunity to learn the new style while attempting to formulate his own version of the genre in a place where the latest trends were slow to develop. The so-called suites (BeRI 3-6, 8, 102) all show evidence of this stylistic and generic transformation. The earliest of these were probably the Partita/Suite in C minor (BeRI 8) and the Suite in D minor (BeRI 6), the former in eight movements and the latter having but six. The former has the typical source-critical instability of nomenclature found during the period $1738-40-$ it is entitled in the authentic sources as "Sinfonia overo Partita" à la Schulz-and the appearance of obbligato instruments mirrors the ripieno concerto that Roman observed in Italy. It retains some of the older severe French overture style in the first two movements, although the introductory Largo's dotted rhythms are smoothed out somewhat and the second movement's fugue owes more to Corelli than Handel with its leap of a diminished seventh in the main theme. Baroque suite remnants are found in the fourth movement Gigue and the fifth movement Siciliano, but the seventh movement, a minuet, is strikingly modern, as is the fast-paced Italianate Presto that follows. Because of the mixed styles, the insecure generic nomenclature, and the conscious attempt to imitate at least partially the new Italian style, it is likely that this work was written shortly after his return to Stockholm, probably in $173^{8}$, when memories of his experiences were still fresh in his mind. It is even possible that this work is a pasticcio, with movements cobbled together from various periods of his life. Bengtsson noted that some stylistic incongruity was evident in this work (and others), although he preferred a timespan in the early 173 os rather than later. ${ }^{25}$

The sixth movement of the Suite in D minor has an indication that might be of some aid in the dating process; the sixth movement

${ }^{24}$ See Bengtsson, Roman, 36, 41; Morgenroth, Agrell, Five Symphonies, xx. According to the payroll books, Agrell received the sum of 120:28 Thalers for "Musicalierne från Cassel." The contents of this music is not specified.

${ }^{25}$ Bengtsson, Roman, 404 . 
is by S. Buschenfeldt, one of Roman's colleagues who died in 1740 . Bengtsson noted that this Suite, the other sources of which also list it as a symphony or partita, was stylistically more advanced than the one in C minor: "The suite was remarkably closer to Roman's symphonies with respect both to formal references and the many details in question." ${ }_{26}$ The homophonic texture, the use of triplet and sixteenth accentuation, and the rhythmic-melodic structures all point to the new galant style; Buschenfeldt's contribution, evidently placed into the work by Roman himself, is the stylistically least advanced of the movements. ${ }^{27}$ The instrumentation, however, is not far removed from the C-minor Partita, indicating a similar span of between 1738 $4^{0}$ for its composition. This is also circumstantially confirmed by the sources, which indicated the variable nomenclature of the presymphonic development. That Roman had a high regard for this piece can be seen in its partial reuse, evidently some two or three years later, as a "Sonata" for orchestra (BeRI 103), about which more will be said presently.

The Suite in F major (BeRI 4 ) appears stylistically to have been written in about the same time period, although in its present form it lacks the original French overture introduction..$^{28}$ The orchestration of the first is similar, with two oboes/flutes more or less doubling the violins. From a formal standpoint, there are some indications that this work too may be a sort of pasticcio, including both older and newer material. The overture, third, and final movements are typical for the Baroque suite, representing respectively the French Overture, sarabande, and gigue movements. But the other movements, especially the fast-paced perpetuum mobile of the fifth and the muted strings of the sixth, indicate the incipient homophonic galant style. Like the Partita in C minor, this work is still not stylistically unified and therefore probably belongs also to the period immediately following his grand tour, $173^{8-40 .}$

In the early 1740 , there were several circumstances that caused Roman to re-evaluate his style, resulting in his beginning to compose in an almost completely modern fashion. First, the symphony itself

${ }^{26}$ Bengtsson, Roman, 405: "Sviten står nämligen såväl i formellt hänseende som i fråga om många detaljer betydligt närmare Romans sinfonior."

${ }_{27}$ See Bengtsson, Roman, 136 . Bengtsson speculates $\left(4^{\circ} 4\right)$ that the insertion of Buschenfeldt's movement could have been a memorial to a recently deceased friend, in which case the year $174^{\circ}$ would give a terminus post quem for the work and would explain its use as "Parentations-Musik" in one of the later sources.

${ }_{28}$ Its companion piece, entitled an Overture/Suite in F major (BeRI 5), however, retains the overture, although it lacks all but two of the rest of the movements. This work, which will be discussed presently, probably represents a second "updated" version. 
emerged from its developmental stage as a popular genre. Although it was clear to theorists and historians of the time that something was happening to replace the independent French Overture (or Sinfonia da chiesa), it was not until the period $1740-45$ that publishers began to issue works under the unified titles Sinfonia/Symphonie or Ouverture for use as purely concert instrumental works. In 1745 Johann Adolph Scheibe, a German composer resident in Copenhagen, published a revised edition of his periodical Der critische Musicus, in which he defined the genre:

Sinfonias comprise a three-fold genre: to wit, those used for church pieces, those for theatre, and other vocal pieces, and finally those intended as purely instrumental works, without any connection to vocal music. ... Thus we have sacred, theatre, and chamber symphonies. ${ }^{29}$

This is significant, because in the original edition of the journal published during the years $1738-49$, a definition of the symphony was missing, indicating that it had not yet been clearly defined. This historical description, along with Scheibe's further admonition for composers interested in instrumental works to adhere to the galant style and the appearance in print of sets of symphonies meant for performance either by professional or amateur musicians (such as Franz Xavier Richter's Six grandes simphonies published in Paris by Duter, Boivin and LeClerc in $1744^{30}$ ), at once gave Roman both further examples of the style and a more solidified concept of the trend that he had been attempting to absorb during the years since his grand tour. Second, when Queen Ulrika Eleonora died in 1742, a period of uncertainty over the heir to the Swedish throne ensued. This was resolved only the following year with the elevation of the Duke of Schleswig-Gottorp, Adolph Frederik, to crown prince. When he arrived in Stockholm in 1743 , he brought with him his entire Kapelle led by Hinrich Philip Johnsen, which was maintained separately from the Hovkapell. This meant an influx in the number of musicians to the Swedish capital, resulting in increased competition for Roman

29 See Johann Adolf Scheibe, Der critische Musicus, Neue, vermehrte und verbesserte Auflage (Leipzig, 1745), 596. See also Walin, Schwedischen Sinfonik, 309 and further references there.

3o RISM R 1331 . This series of symphonies, whose sources appear throughout Europe indicating relative international popularity, actually consist of two sets of six works totaling twelve in all. They are scored for a string orchestra with figured bass and can be reckoned as one of the earliest publications (in parts) of the modern symphony. See Bertil van Boer, Franz Xavier Richter, Five Symphonies, The Symphony 1720-1840 Vol. C 14 (New York, 1985), xviii. 
and a necessary change in the programming of the Riddarhuskonserter. ${ }^{31}$ On the positive side, it meant that a new orchestral sound, including horns, was introduced, offering composers of the city an expanded timbral variety.

The years $1740-45$ were pivotal years in Roman's stylistic development, since he had to assimilate all of these changes quickly. No longer was he given the luxury of slowly adapting his own style through experimentation, and during this period, one finds that a rapid growth in the new galant style was experienced. There are at least four works that show this change; although they too are transitional works, there is stylistic evidence that Roman continued his attempts to redefine his own style through them. Possibly the earliest of these is the "Sinfonia overo Suite" in E major (BeRI 3), a fivemovement work scored for strings alone. The broad formal overview of this work shows that it is an arch form, with a pair of relatively fast movements (a Gustoso plus a Vivace and two Allegros, all in E major) flanking an Andante in the subdominant (A major). All five of the movements are in a binary form. Although the first two have some of the characteristic dotted rhythms and counterpoint of the French overture, the Vivace, with its $\mathbf{8}$ descending scalar theme, is most awkward contrapuntally, for it devolves into a brief series of imitative passages that all end with more or less homophonic statements. The final movements contains stylistic incongruities; the first Allegro is gigue-like while the homophonic second Allegro exhibits rhythmic and melodic characteristics, such as louré or Lombard rhythm, commonly found in the galant style. This stylistic ambiguity did not go unnoticed by Bengtsson, who stated: "No clear thematic contrasts are to be found, but in this symphony the Fortspinnung technique and pronounced tendency to use four-measure phrases are motivically varied in a way that Roman would retain and develop in his later works." ${ }^{2}$ In his dissertation on the instrumental works, he noted that there were stylistic similarities both with early works like the Golovin music and later symphonies; since there seemed more of the former, he reluctantly concluded that this work was written in the 1730 . 33 Turning the question on its head, however, raises the issue of whether galant trademarks could be found prior to his grand tour in 1735 ; the fact that older material resurfaces later is not problematic since numerous composers, including Roman's mentor Handel, often reused very early works in later compositions. If the style itself is taken as the

31 See Bengtsson, "Instrumentale Gattungen," 100.

32 Bengtsson, Roman, Six Symphonies, xx.

33 Bengtsson, Roman, 405. He goes one step further, by stating that it is probable that this work was written as early as $1730-35$, based solely upon these statistical results. 
criterion, then it becomes more probable that this work belongs to the transitional phase of his production. Since it is a considerable advance on the multi-movement suites suggested for the period $1737-4^{\circ}$, it is likely that this symphony dates from ca. $174^{0}-4^{2}$, about the time that Roman appears to have become aware of the stabilization of the genre, for the internal evidence points to an attempt on his part to write (or at least put together) a shorter, more cohesive work that fits the definition of neither suite nor symphony precisely.

There also exist two other experimental works that show Roman consolidating his instrumental style; the so-called string sonatas $a 3$ in D minor (BeRI 103) and B-flat major (BeRI 102). Both are written for three parts, although it is implied that the violin part is to be performed by both first and second violins unisoni. The first is a barely-revised version of the Suite in D minor (BeRI 6), which lacks the latter's second movement but includes the insertion movement by Buschenfeldt. Why Roman would make such a revision is unknown, but it is significant that the reduction in orchestration, eliminating the doubling winds and consolidating the violin parts at points, seems to point to an attempt on the composer's part to pare it down to the three-part sinfonia standards that seem to have appeared in Europe during 1739-40, particularly in the published works of Sammartini and others. This means that it was composed concurrently with, or shortly after, the Symphony in E major as a practice model for his final transition period work, the Sonata or Symphony $a 3$ in B-flat major, which can be subsequently dated during the next year or so. This work, whose style and sources Bengtsson clearly noted as being "the 174 os rather than earlier," is likewise in five movements, showing in its thematic development and rhythmic structures a similarity to the E-major symphony/suite. 34

It was during the early 174 os that Roman's performances began to receive some competition. Prior to this time, the public concerts had mostly concentrated upon sacred music, but during $174^{\circ}$, beginning on 3 December, a second series of concerts appears to have been offered by a "Musikaliske [sic] Academi" at the Rådhus, which were held every Wednesday through Easter. 35 This had serious ramifica-

34 Bengtsson, Roman, 405. Bengtsson particularly notes that the fourth movement's "pleasant theme and melodic development" would have been completely foreign to Roman's earlier period, being reminiscent of the final movement in a relatively late Symphony in F major (BeRI 10).

35 Vretblad, Konsertlivet, 142. Vretblad, of course, notes that there is no connection with this series and the Royal Academy of Music founded in 1772 . Here, however, there seems to have been a misreading of the eighteenth-century practice of calling many concerts academies, the title of which was meant only to show that a group of musicians, the "academy," merely sponsored the concerts. 
tions for Roman's concerts, for by 1743 there were indications that his were in serious financial difficulties. In a letter dated 9 July 1743 , his second in command Per Brant wrote that he himself had gone into debt to salvage the series..$^{6}$ This meant that this competitor was providing the Stockholm public with something they were not receiving in the official public series, namely popular genres. Indeed, a concert produced by Leopold Commano at the Rådhussal on 23 March 1743 featured music "de la composition des meilleurs Maîtres de ce tems [sic]," which implies the latest foreign works and probably included some of the earliest symphonies of the period. This may have been the reason for Roman asking his colleague Agrell and perhaps others to forward to him some of the latest works from the Continent, which they did beginning in 1742 .

This circumstance may have been altogether too much for Roman to endure, however, for it is clear that he was considering a permanent withdrawal from Stockholm during the spring and summer of that year.37 But in October, the new crown prince arrived in the capital with his court amidst "Musique och dantz," signaling the dawning of a new era. Roman had no doubt heard of Adolph Frederik's private Kapelle beforehand, and it seems logical that he might even have been anticipating their arrival as a means to expand his own musical style. He certainly knew that a combination of the two orchestras would create a fuller sound, and the addition of the horns would have enlarged the texture considerably. But he was probably fairly unfamiliar with these instruments, and it appears likely that he once again attempted an experimental work that would serve as a test-bed for future works.

In his instrumental oeuvre there is one piece that appears to be just such an attempt, the Ouverture/Suite in F major (BeRI 5 ), which is a complete revision of a suite written several years earlier (BeRI 4 ). Why he chose this work is unknown, but he appears to have reduced it in size from seven movements to four, which is in keeping with the trend toward the traditional three- or four-movement form of the early symphony that is evidenced in his other works of this period. He retained the French Overture opening movements, combining them

${ }^{36}$ See Ollalo Morales and Tobias Norlind, Kungliga Musikaliska Akademien 17711921 (Stockholm, 1921), 5. Brant proposed that the musicians of the series be supported by a state lottery which would also be used to establish a Royal Academy of Music. This was not instituted, however, until $177^{2}$, long after both his and Roman's death.

37 See Vretblad, Roman, 34-36; Bengtsson, Roman, 41-43; it is also possible that progressive hearing loss may have been another cause for his consideration. His letter to Wasenberg dated 14 January 1743 indicates that he felt "svårligen angrepen af en siukdom som ännu varar" [heavily attacked by an illness that still hangs on]. 
with the cantabile Larghetto (the first surviving movement of BeRI 4) and the fast-paced 2 Presto (BeRI 4 , Movement 3 ). This combination resembles the three-movement Sinfonia, albeit with an extended first movement. Bengtsson expressed some misgivings about this opening being originally intended for BeRI 4 because of the orchestration, but the horn parts are so primitive and non-contributory to the whole, that they can be omitted (or occasionally replaced with the doubling winds) without damaging the structure of the movement. $3^{8}$ Whether or not Roman actually intended this revision to be performed at one of the concerts is unclear, but the multiplicity of sources does indicate that the work was accepted, though perhaps not by the intended party. Indeed, it became clear rather quickly that the Ducal Kapelle was not going to be integrated into the Hovkapell, and moreover, their establishment of a rival series the following year-they actually usurped the Rådhus concerts-gave Roman notice of their intention to compete with the understrength and economically-weak official court orchestra. Finally, with their connections in Northern Germany, these rivals had access to the most modern genres on the Continent, which they no doubt obtained directly and put to use immediately without the long, tedious process of development that Roman had undertaken. While it is true that Roman was independently moving toward the traditional symphony of the period, his progress was rather more deliberate than the mainstream, and when his sphere of influence was penetrated by those who were familiar with the latest trends of the new genre, his own efforts could not be seen in any manner other than plodding and out of date. The tentative chronological order of this second period can be seen in Table 2 .

It is hardly surprising, therefore, that Roman felt himself bested to some extent by the newcomers, especially since they clearly made an effort to establish themselves as competitors both at the separate courts of the king and crown prince, as well as in the concert hall. In February of 1744 he appears to have left Stockholm after complaining about uncollegial activities-meaning the new musicians and their competition-and leaving the Hovkapell in the hands of Brant. The wedding of Adolph Frederik and Prussian Princess Lovisa Ulrika in 1744 brought Roman out of semi-retirement to compose the wellknown and festive Drottningholmsmusik, a gigantic suite (or actually series of two suites totaling some thirty-three numbers) that was

$3^{8}$ Bengtsson, Roman, $35^{\circ}$. Bengtsson himself notes about the horn parts: "Dess hornstämmor ha nämligen ingen fullt självständig och därigenom oumbärlig funktion." [Its horn parts thus have no full independence and therefore no essential function.] 
TABLE 2

\section{Symphonic Works by Johan Helmich Roman \\ Transition Period (1737-45)}

\begin{tabular}{|c|c|c|c|c|}
\hline Work & $\begin{array}{l}\text { Move- } \\
\text { ments }\end{array}$ & Bengtsson No. & Date & $\begin{array}{l}\text { Original Title/ } \\
\text { Comment }\end{array}$ \\
\hline $\begin{array}{l}\text { 1. Suite in } \mathrm{C} \\
\text { minor }\end{array}$ & 8 & BeRI 8 & $173^{8-39}$ & Sinfonia overo Partita \\
\hline $\begin{array}{l}\text { 2. Suite in D } \\
\text { minor }\end{array}$ & 6 & BeRI 6 & $173^{8-40}$ & $\begin{array}{l}\text { Parentations-Musique } \\
\text { Partita/Suite/Sonata }\end{array}$ \\
\hline $\begin{array}{l}\text { 3. Suite in F } \\
\text { major }\end{array}$ & 6 & $\mathrm{BeRI}_{4}$ & $173^{8-4^{0}}$ & "Suite oue Sinfonia" \\
\hline $\begin{array}{l}\text { 4. Symphony } \\
\text { in E major }\end{array}$ & 5 & BeRI 3 & $174^{0}-4^{2}$ & $\begin{array}{l}\text { Suite/Sinfonia overo } \\
\text { Suite }\end{array}$ \\
\hline $\begin{array}{l}\text { 5. Sonata à } 3 \\
\text { in } D \text { minor }\end{array}$ & 5 & BeRI 103 & $1740-4^{2}$ & $\begin{array}{l}\text { Revised version of } \\
\text { BeRI } 6\end{array}$ \\
\hline $\begin{array}{l}\text { 6. Sonata à } 3 \\
\text { in } \mathrm{B} b\end{array}$ & 5 & BeRI 102 & $1740-4^{2}$ & "Introduttione" \\
\hline $\begin{array}{l}\text { 7. Ouverture } \\
\text { in F major }\end{array}$ & 4 & BeRI 5 & $1743-44$ & Ouverture/Suite \\
\hline
\end{tabular}

performed for the first time on 18 August. Because of the political nature of the festivities, the two orchestras were subsumed into one, and Roman, who apparently wrote a majority of the work under extremely trying circumstances - his second wife died in June, 1744nonetheless created a substantial composition that has been considered his best work.39 There is little in this occasional music that would lie in the symphonic realm, save for several movements that are clearly written in a more homophonic style. The models that Roman had were certainly not current, for long suites of this sort were atypical of the new galant style. Indeed, he had to reach back into his own past; the instrumentation, layout, and structure owe more to Handel's Water Musick of 1718 , his own Golovin Music of 1728 , and Telemann's Hamburger Ebb- und Fluth of $173^{\circ}$ than anything current in the 1740 . But the music itself is kaleidoscopic, as Bengtsson noted:

In general, the funeral music is characterized by great fluidity. Throughout Roman chooses different, sometimes a bit unconventional formal solutions, works with all possible structures as simple

39 See Bengtsson, Roman, Six Symphonies, xvi; Johnson, Musiken i Sverige, 54-56. Roman even makes mention of the divided orchestral forces; in No. 8, an E-flat major Lento he notes that two orchestras ought to perform it, an indication of the separateness of the Hovkapell and Ducal Kapelle. 


\section{THE JOURNAL OF MUSICOLOGY}

as brief dance forms and small occasional pieces, and varies the rhythms at least as often as he does the keys. $4^{\circ}$

And if its intent was to please both the older members of court and the newcomers, it certainly succeeded, but Roman's ulterior purpose was to demonstrate mastery both of form and instrumentation, which was likewise accomplished. If he hoped that this would be a means of uniting the disparate orchestras into a single, well-disciplined entity, this was not to be achieved, for shortly after the nuptials were celebrated, the Ducal Kapelle, in what seems like a calculated move to maintain its separate identity and achieve prominence in Stockholm, took over the Rådhus concert series. The concertmaster, Anton Perichon (ca. 1719-ca. 1778), quickly organized a Fall subscription series at the Rådhus featuring the Ducal orchestra in a serenata Der Vergnügende Streit über den Vorzug des Vergnügens [The Entertaining Debate over the Advantages of Pleasure] followed by "Instrumenter, Concerter, Solo och Simphonier." $4^{1}$ This was not only insulting to Roman personally, it also forced the Riddarhus concerts to be given only occasionally for the next several years.

The royal marriage gave the Ducal Kapelle further access to the musical production of the Berlin court, including symphonic music by both Johann Gottlieb and Carl Heinrich Graun, Johann Quantz, and others. $4^{2}$ It also meant a direct connection between Sweden and the Continent, which in turn implied that musical styles would be sent directly north as they appeared. Perichon's concert, which included symphonies, though which are still open to debate, was symptomatic of this new development, and it is probably through the Ducal Kapelle's efforts that the modern symphony finally made its appearance in Stockholm. For Roman, whatever the personal affront that this represented, it was an opportunity to learn first hand about the latest

$4^{\circ}$ "Överhuvudtaget kännetecknas bilägermusiken av stor omväxling. Roman väljer hela tiden olika, ibland lite okonventionella formlösningar, arbetar med alla möjliga format ned till korta danssatser och små stämningsstycken och varierar taktarter minst lika ofta som tonarter." Cited in Johnson, Musiken i Sverige, 57; originally written as text commentary to Johan Helmich Roman, Drottningholmsmusiken, National Museums Orkester, conducted by Claude Génetay (Polar PLCD 361, 1982).

4' Vretblad, Konsertlivet, 25, 143. This short season lasted until Advent, when a second "andelig Serenata" entitled David und Jonathan was introduced along with "Diverses Cantates \& Simphonies entremélées d'autres Pièces de Musique," no doubt the same popular pieces as in the foregoing concerts. Telemann's intermezzo Pimpinone was premiered in January during the Carnival. Johnsen's participation is first mentioned in concerts from the following year. According to Lovisa Ulrika, the Ducal Kapelle also gave a private court concert each Sunday. See Holger Nyblom, "Lovisa Ulrika och musiken vid svenska hovet," Svensk tidskrift för musikforskning IV (1922), 28.

$4^{2}$ Nyblom, "Lovisa Ulrika," 28. 
forms of the genre. As a musician, he was no doubt interested in what to him was a final form, even though this effectively circumvented his own experiments in the field. Although these Continental works finally demonstrated that his own attempts were not always viable, it is likely that they gave him models for further study; such would have allowed him to switch suddenly to the new genre without further intermediate steps.

In January 1745 Roman retired to his small estate of Haraldsmåla, near Kalmar in Småland. He received his salary and a further supplement in November of 1745 , when he was named Hofintendent by Frederik I, showing that, despite his absence, he maintained close contact with the court.43 This leave, originally intended to be one year but extended indefinitely after 1747 , was officially accomplished through the mediation of a new patron that Roman had acquired, Count Adam Horn, whose residence Fogelvik at Tryserums parish in Tjust lay relatively close to Haraldsmåla.44 Roman spent some considerable time during the next year or so at Fogelvik, both recuperating his health and composing. The estate had an active musical life -in 1746 a new organ was dedicated at the local parish church with musical festivities - which was conducive to musical composition. Roman may have taken with him, or had sent to him, some of the early four-part published symphonies from the Continent, such as Richter's Six grandes simphonies Op. 1, which were available in Stockholm. 45 That he assiduously studied these is witnessed by the quantum leap in style in his only two datable works; the Symphony in F major (BeRI 10) written as part of a larger "Printz Gustafs Musique" celebrating the birth of a new crown prince, later Gustav III on 24 January 1746 , and the Symphony in G major (BeRI 15), dated Fogelvik 2 August 1746.

Since there is a secure dating for these pieces, it is useful to consider the various items that identify them stylistically. First, the Symphony in F major was apparently written as part of a larger celebratory work, possibly a multi-movement suite. The circumstances, the birth of Sweden's first crown prince in fifty years, were cause enough for a commission, but the fragmentary state of the source material and its peculiar designation as the "middle parts to Printz Gustafs Musique" beg the question of whether Roman was actually asked officially to write the music. The Ducal Kapelle, of course, had its own stable of those considered modern composers, and since this was an event particular to their ducal family, it would have been more likely

43 Bengtsson, Roman, 47-48. The protocol letter is quoted in extenso.

44 Bengtsson, Roman, $5^{1-52}$. Horn acted as intermediary in requesting the leave.

45 See van Boer, Richter, Six Symphonies, 18. Manuscript scores compiled from the parts of this edition exists at the Musikaliska Akademiens Bibliotek (Od-R I:1). 
that someone like Johnsen would have received the commission. Roman himself must have felt somewhat ambiguous about his project, perhaps even uncertain whether or not it would be accepted, for he seems to have kept this three-movement sinfonia as a unit separate from the now-lost other movements. This instance is also supported by the varying instrumentation; versions both with and without the two horn parts exist. ${ }^{6}$ All three movements are in $\mathrm{F}$ major, and though they show differences in tempo, this fact reinforces the ambiguity between symphony and suite that Roman must have had. But there is a considerable advance in style between this work and the three-part Symphony in $G$ major from nine months later.

The sole dated work appears to have been the first real product of Roman's symphonic study of the new symphony, which may account for the reason behind the precise chronological designation. The orchestration was apparently only $a 4$ in the autograph, with the second violins and violas lacking (or meant to be performed perhaps colla parte with the extant voices), although other sources add the missing inner voices.47 The dotted rhythms of the opening bars of the first movement are reminiscent of early Richter works, like the Symphony in $\mathrm{F}$ major published in 1744 , as is the thematic structure of both other movements (see Example 1). The rhythm follows the galant pattern by using small contrasting motives, elaborate sequencing, and weak beat ornamentation, while the piece is thoroughly homophonic throughout. While it may be premature to say that this signals a renewed interest in redefining his style according to the most modern trend of the time in order to compete with the Ducal interlopers, there is a sense of permanent change about this symphony, for which Roman may have been encouraged by Horn and inspired by the apparent popularity of sets like Richter's Six grandes simphonies. The four-part writing guaranteed that minimal forces would be required

$4^{6}$ See Bengtsson, Roman, 141-42. Sources in Stockholm and Lund have the work $a 4$, i.e., for strings only, and the horn parts themselves are simple enough to have been omitted at will. In the two sketches that survive of other movements to the suite (BeRI $\left.10^{\frac{1}{2}}\right)$, however, the horns are apparently more integrated, indicating that Roman may have planned from the beginning that the symphony be extracted separately. The piece is analyzed briefly in Hedwall, Symfonin, 29.

47 See Bengtsson, Roman, 145; idem., Roman, Six Symphonies, xxii and 103. There exist oboe and horns parts for this symphony, which may or may not have been written by Roman. Their style is certainly consistent with other parts of authentic symphonies. Although the inner parts lend the work a more modern texture, it can be performed $a 3$, with the violins doubling the melody line and the violas the basso at the octave. This, however, hardly remains consistent with the textures of the rest of the four-part symphonies. 
EXAMPLE 1. Comparison of Richter and Roman First Movement openings.

a) Franz Xavier Richter, Symphony in F major (1744), mvt. 1, mm. 1-4.
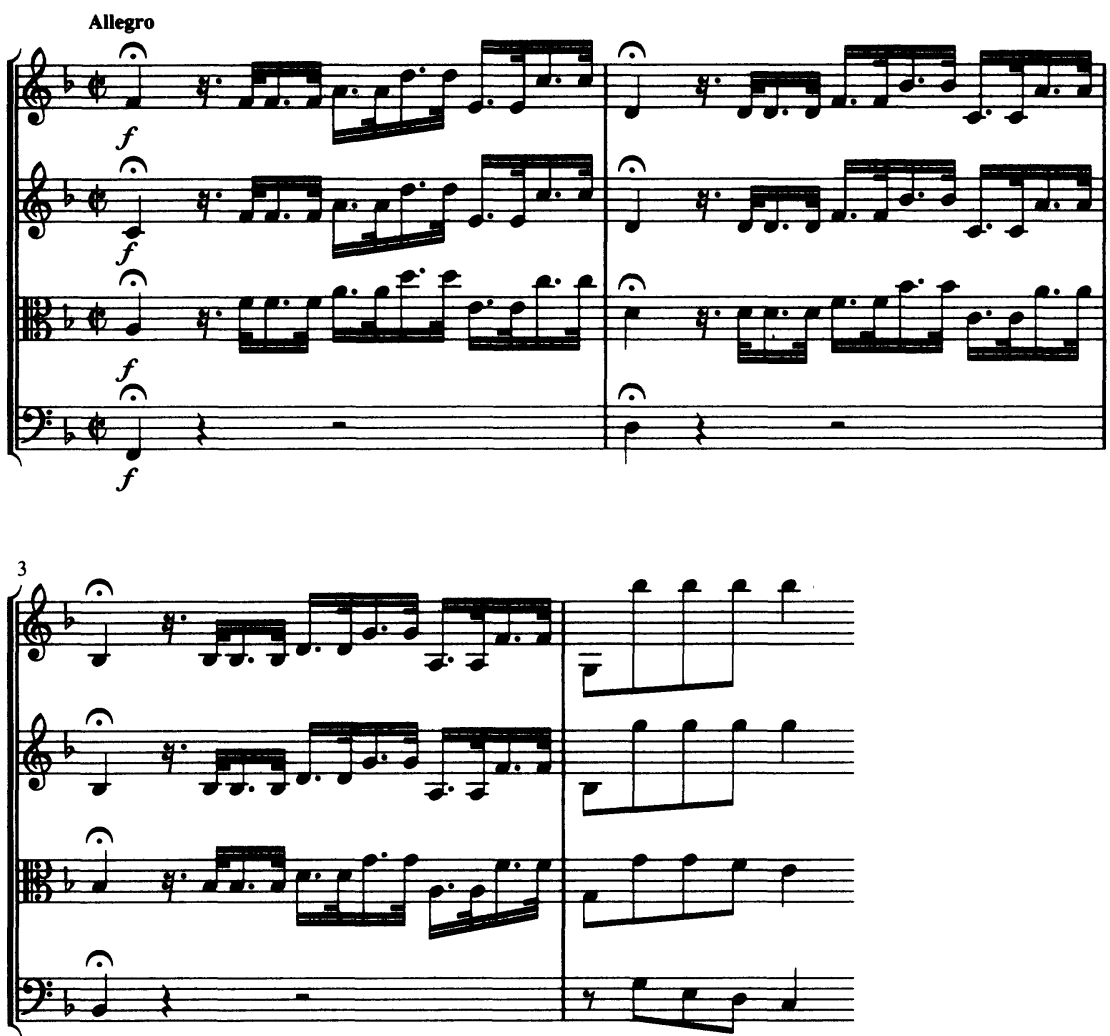

to perform the works, but the rhythmic complexity and clearlydefined thematic and formal structure would have maintained their currency with both musicians and audiences.

If this is true, then the Symphony in $G$ major was probably the first of a series of works $a 4$ that may have been intended to imitate the Continental sets, and, indeed, Roman may even have entertained the thought of publishing them in Sweden or elsewhere. Given the progressive similarities in terms of style, orchestration, and form, it would seem that a series of five more four-part symphonies in three movements were all written within a period of between six to eight months following the Fogelvik work. These works (B-flat major BeRI 11, D major BeRI 23, A major BeRI 26, D minor BeRI 27, and B-flat 
EXAMPLE 1 (continued)

b) Johan Helmich Roman, Symphony in G major (BeRI 15), mvt. 1, mm. 1-4.
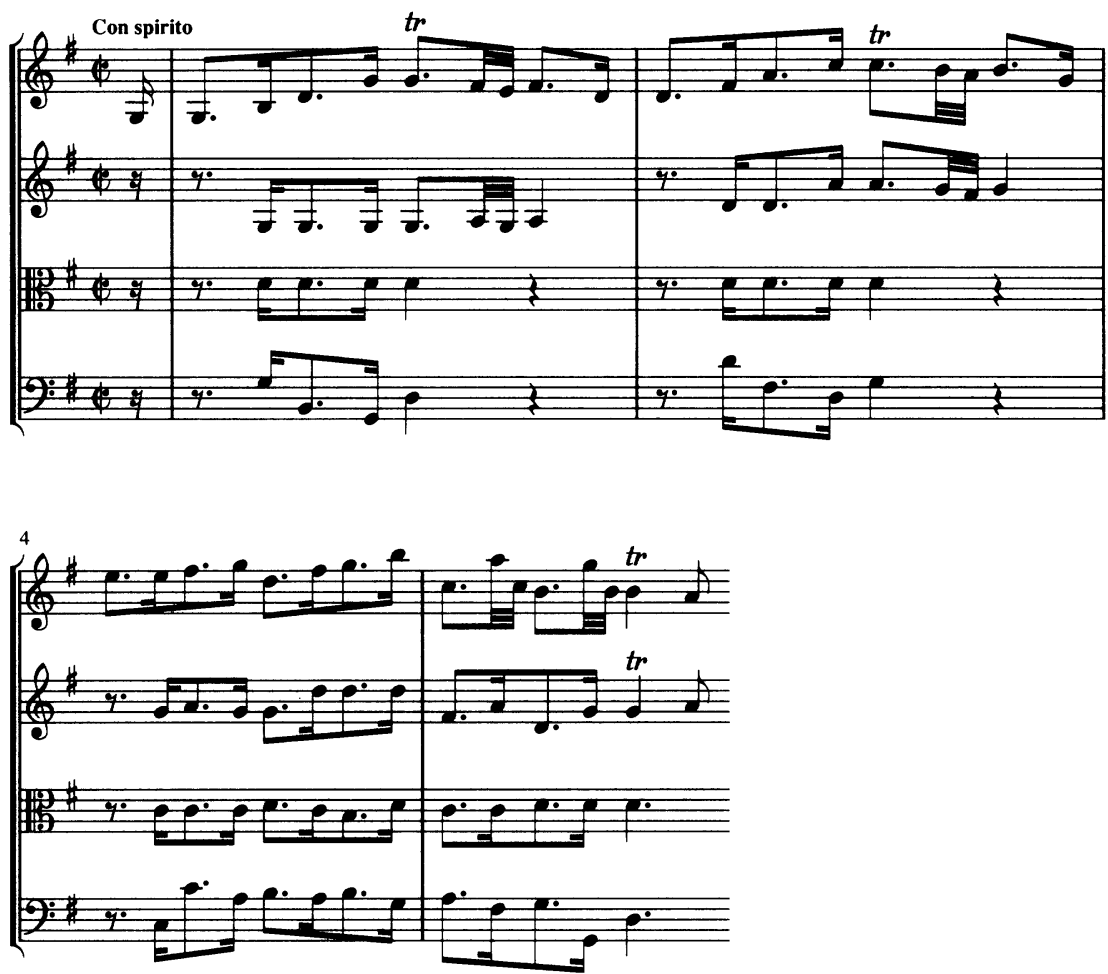

major BeRI 28) all contain various galant trademarks, such as the sordino Siciliano second movement of BeRI 24, the sudden harmonic shift to the unusual relative minor (F-sharp) minor in BeRI $26,4^{8}$ and the rapid arpeggiated main theme of BeRI 28 . These are all chamber symphonies in the most Classical sense, reflecting Roman's ability to absorb the popular style completely. It may also be suggested that, once finished with this set of six, the composer may have considered a second genre of the symphonic trinity described by Scheibe, the Sinfonia da chiesa, which differs from the chamber symphony by reversing the order of fast and slow opening movements. This type, which H. C. Robbins Landon defines as a Sonata da Chiesa symphony,49 is reflected in the three-movement Symphony in F major

$4^{8}$ See Hedwall, Symfonin, 30 .

49 See H. C. Robbins Landon, The Symphonies of Joseph Haydn (London, 1955), 253. 
(BeRI 17), likewise scored for strings alone, which begins with a solemn Grave sostenuto movement. The turn toward the sacred symphony would have fit well with the composer's main focus during this year-and-a-half of leave, the adaptability of sacred music to the Swedish language.

The terminus ante quem for these symphonies appears to be June of 1747, when Roman returned briefly to Stockholm to fulfill his duties while his petition for permanent leave of absence was reviewed. $5^{\circ}$ Although his main goal during this time was to prepare for a formal presentation to the Vetenskaps Akademi of a sample sacred composition demonstrating the adaptability of the Swedish language to music, it is likely that he took the opportunity to plan the revival of the Hovkapell and Riddarhuskonserter with Brant, as well as to study the latest music that was being imported and performed at the Rådhus by the Ducal Kapelle; knowing that his permanent leave had been granted probably relieved a great deal of the competitive pressure, allowing him to observe the musical trends objectively. It is also likely that he either showed or delivered to Brant his recently composed symphonies at that time.

By 1747 further increases in the scoring to incorporate a pair of winds (either flutes or oboes, or sometimes both) as well as the development of the four-movement symphony were beginning to appear; Johan Agrell had just completed several symphonies in more than three movements that were sent to Sweden, possibly to Roman himself..$^{1}$ It is doubtful that the composer was unaware of this circumstance, which would doubtless have shown him that the threemovement church symphony was not the most viable form. If he was going to continue to produce church symphonies, then they would have to be in at least four movements. Moreover, the latest works augmented the orchestration, which may have been problematic, if he were relying upon the Hovkapell to perform his works; although they had generic wind players, they lacked the horns of the Ducal Kapelle, and further, the winds were more used to playing colla parte with the strings rather than as harmonic reinforcement, their role in the new style. Nonetheless, Roman might have taken this as another signal to continue his experimentation.

There are a number of symphonies that show this further development and may in fact date from the period $174^{8-50}$, when Roman

$5^{\circ}$ On 20 June 1747 Roman requested permanent salaried leave, with Per Brant to be appointed as his successor. The king acted on the petition positively only a week later, but it was not to take effect until early $174^{8}$, for Roman remained at his post through the Summer and Fall. See Bengtsson, Roman, 52; Vretblad, Roman, 40-41.

${ }^{51}$ Morgenroth, Agrell, xxvi. These were published as his Op. 1. 
returned to Haraldsmåla. The first are two church symphonies in four movements (C major BeRI 13 and G major BeRI 9) that are scored for strings alone. The opening slow movements of both works are extremely brief; the C-major symphony begins with a Baroque sequence, although there is a bit of rhythmic incongruity in the G-major first movement between the opening legato and the anticipated dotted rhythms of the third measure. The following Allegro movements are characterized by both galant melodic and rhythmic figures fitted into a contrapuntal framework, lending them a mixed quality. The final movements are typical $\mathbf{s}$ stylized dances with octave cadential figures that are also fairly galant in character. The brevity of the individual movements, which make these two symphonies far shorter than the three-movement string symphonies (with the exception of the remaining da chiesa BeRI 17), appear to show that Roman was hardly comfortable with the form or the style, since he was certainly aware by this time of the expanding formal structures; indeed, both the slow first movements act as short introductions to the following allegros, giving the entire work a sort of overall threemovement form..$^{2}$ Since the superficial counterpoint of the opening does seem to contrast with both earlier works and the galant style of the last movements, a sense of experimentation pervades these symphonies. But his last work for strings only, the Symphony in D major (BeRI 14) seems to have taken yet another leap forward. It is a true four-movement work, in which the slow introduction, a series of definitive three-note chords with upbeats, functions only as a five-bar declamation presenting the triplet-duple main theme that contains a typical galant rhythm. The third movement is based upon a series of Richteresque syncopations, while the fourth movement is an added allegro staccato based upon a song attributed to Roman entitled "Äta litet, dricka vatten [Eat little, drink water]," which in its brief twelvebar form may have had some satirical significance. 53

Beginning with the Symphony in G major (BeRI 21 ), Roman seems to have expanded his orchestration to include obbligato wind parts. The sources for this symphony variously list a flute or an oboe as a substitute or alternate for the first violin part. This blends the concept of concerto and symphony, almost as if he were experimenting with expanded textures; the first and last movements are some of the longest that Roman wrote and, with regard to thematic development, the structure (a modified da capo aria) anticipates the sonata form. Here it seems as if the use of this wind instrument, which may

$5^{2}$ See Hedwall, Symfonin, 27.

53 See Hedwall, Symfonin, 31 . 
or may not double the uppermost string part is an attempt both to increase tonal variety and to see if this avenue of development is a fruitful one. Several other symphonies also show the expansion of the instrumental complement: the Symphony in A major (BeRI 16), which reverts to three-movement form, but has a pair of flutes that serve as harmonic and melodic support, the latter in a lilting arietta slow movement; the Symphony in B-flat major (BeRI 29) which uses a pair of oboes both to double the strings in the French opening movement and to provide harmonic underlay in the fast-paced finale; and the Symphony in E minor (BeRI 22), where a pair of flutes are used in the pastorale Pifferi which has some thematic similarity to a similar movement in Handel's Messiah.54 In the final work, the Symphony in D major (BeRI 23), Roman allows the oboes to have a more or less independent role throughout the entire work, although he does change to a pair of flutes in the slow movement, as was common during the period.

It is difficult to tell anything from these eight works, apart from the fact that they appear in some sense to be linked as experimental symphonies that show attempts at writing in a four-movement form that becomes less and less associated with the church symphony over time, and that all eight demonstrate a progressive instrumentation, through which Roman gradually appears to be mastering the introduction of a Classical woodwind texture into his symphonies. There is no evidence that they were written with any particular purpose in mind, save as further progress in mastering a new genre and possibly for use by Brant in the public concert series in competition with the Ducal Kapelle. There is some circumstantial support for the latter. In October of 1748 Brant instituted a revival of the Riddarhuskonserter on 1 October, offering a series that took place on each Saturday throughout the winter. Although the content of the concerts is not mentioned, the announcement noted that it was "His Royal Highness's Kapelle especially strengthened [H. K. Höghets Capell, med en ansenlig förstärkning]," which allows no other interpretation than that Brant was able to increase the size and probably number of instruments for the concerts. 55 This may allow some speculation that, if Roman's symphonies were written for the Riddarhuskonserter to be performed competitively as he and Brant may have discussed in the fall of 1747 , then it is possible that all of these works noted above were written in the space of seven or eight months in $174^{8}$. The relatively

54 See Hedwall, Symfonin, 27.

55 Vretblad, Konsertlivet, $14^{8-49}$. The Ducal Kapelle also tried to compete, but their efforts were limited to a pair of large concerts at the Rådhus on 15 October and 2 November. 
large number of sources would seem to support this suggestion, although it is also possible that a larger timespan, $174^{-}-5^{\circ}$, ought to remain under consideration; Bengtsson notes that some of these works may have been performed at the court of Roman's patron, Adam Horn, as well. $5^{6}$

By $175^{\circ}$, the symphony had come into its own as a popular genre; moreover, the use of oboes and horns to supplement the strings had become standard practice for these works. Although there are no critical reviews, it can be suggested that, if the four-movement symphonies were written and performed for the public concerts in 1748 , then they were successful enough to keep the Hovkapell in operation through the following Spring. This might then have inspired Roman to make one last attempt to update his works in this genre by finally bringing their form and orchestration up to the latest galant style. The last four symphonies all show this continued stylistic progress. The Symphony in G minor (BeRI 3o) is apparently the first of these works to use the standard pairs of oboes and horns. Although there is considerable obbligato music in the former in both the second and fourth movement, the last of which appears to be a slightly misplaced and awkwardly barred minuet, the scoring for these instruments is fairly primitive, having only two or three chords. Only in the final movement are they given some measure of prominence, and then only in the first section. After this, Roman seems to have reverted to the three-movement Sinfonia for his last two works, the Symphonies in D major (BeRI 12) and G major (BeRI 19), the first of which calls for two flutes and later for two oboes. Each of these works clearly demonstrates his last word on the subject. The opening movements are characterized by split triadic main themes, full textures, and an attempt at some periodicity. The scoring is freer, with obbligato lines being used in the winds as contrast to the strings. There is some use of string ostinato instead of the more contrapuntal inner voices, and the Symphony in D concludes with a brief scherzando. In all aspects, these are mature works of the galant style with barely a hint of Roman's Baroque heritage, and as such represent the culmination of his development of the genre.

There can be no doubt that these are late works, although it is equally difficult to place them precisely. About $175^{\circ}$ Count Horn had the ceiling of a pavilion on his estate at Fogelvik painted with a circular mural presumably showing the musical forces he had available to him there.57 Of interest are the winds, a transverse flute and what

${ }_{5}^{6}$ See Bengtsson, Roman, "Instrumentale Gattungen," 100.

57 This ceiling mural has been reproduced in Bengtsson, Roman, Plates II/III and Roman, Six Symphonies, xiv-xv. 
appears to be a recorder, as well as a pair of horns, one being played in the alla caccia position (e.g., bell up) and the other being held in a concert position. Since Horn was Roman's patron, this could mean that the symphonies were completed as early as $1749-50$ for private performance on his estate. On the other hand, Roman returned to Stockholm in August of $175^{1}$ to be present at the burial ceremonies of Frederik I and the coronation of Adolph Frederik. Because the Riddarhussal was being used as the official chamber for the lying-in-state of the king from his death in February through the coronation, the concerts could not be held there; they were moved to a small tavern theater at a locale called the Pelikan, where, prior to Roman's arrival, the annual Lenten Passion music was performed, according to Vretblad. After the brief renaissance in 1748 , the Hovkapell appears to have returned to its former dilapidated state, and apparently, according to a pro memoria by Court Chamberlain Carl Reinhold von Fersen dated 20 January $175^{2}$, it was revived yet again only owing to the efforts of Roman that fall. $5^{8}$ On 15 January the Hovkapell played a concert at the Pelikan that consisted of "såväl Vocal- som instrumental-musik [both vocal and instrumental music]"; though the program is not known, this could have been a perfect opportunity for Roman to have introduced his latest symphonies in the new and now completely modern style. It was probably during this time that the grouping of nine symphonies (BeRI 9-17) was made, possibly at the instigation of Roman himself, who may have seen this as a way to preserve what he considered his best symphonies in lieu of publication.

After remaining in Stockholm for several months, Roman returned to Haraldsmåla in the late Spring of $175^{2}$. His compositional efforts for Stockholm must have more or less ceased, for he was fully pensioned and decided to concentrate upon the translation of foreign treatises and the further composition of Swedish sacred music. A brief note by Lovisa Ulrika to Frederick the Great from 1755 confirms that Roman had long since left the Stockholm musical scene. It is therefore unlikely that any of the symphonies date from after $175^{2.59}$ Table Three lists a tentative chronological order for the symphonies dating from this last period of compositional activity in the genre.

${ }_{5}^{8}$ Quoted in extenso in Bengtsson, Roman, $55^{-56}$.

59 See Nyblom, "Lovisa Ulrika," 33; Johnson, Musiken i Sverige, 6o. In this letter, dated 7 October 1755, Lovisa Ulrika remarks on the state of music in Stockholm, with special reference to Roman and his great reputation. But she notes: "A présent il est vieux et ne compose que pour les églises." This contrasts with the palpable contempt in her assessment of the court of Frederik I two years earlier: "Il avait un maître de chapelle sourd, un maître à danse boiteux, un maître d'armes estropié, et le premier peintre aveugle." See Bengtsson, Roman, 87 . 
TABLE 3

Symphonic Works by Johan Helmich Roman

Galant Period (1746-58)

\begin{tabular}{|c|c|c|c|c|}
\hline Work & $\begin{array}{l}\text { Move- } \\
\text { ments }\end{array}$ & $\begin{array}{l}\text { Bengtsson } \\
\text { No. }\end{array}$ & Date & $\begin{array}{l}\text { Orchestration/ } \\
\text { Comments }\end{array}$ \\
\hline $\begin{array}{l}\text { 1. Symphony in } \\
\text { F major }\end{array}$ & 3 & BeRI 10 & $\begin{array}{l}\text { Before } \\
24 / 1 / 1746\end{array}$ & $\begin{array}{l}2 \mathrm{hn}, 2 \mathrm{vn}, \mathrm{va}, \mathrm{b} \\
\text { "Prins Gustafs Musique" }\end{array}$ \\
\hline $\begin{array}{l}\text { 2. Symphony in } \\
\mathrm{G} \text { major }\end{array}$ & 3 & BeRI 15 & $2 / 8 / 1846$ & 2 vn, va, b \\
\hline $\begin{array}{l}\text { 3. Symphony in } \\
\text { B b major }\end{array}$ & 3 & BeRI 28 & $1746-47$ & $2 \mathrm{vn}, \mathrm{va}, \mathrm{b}$ \\
\hline $\begin{array}{l}\text { 4. Symphony in } \\
\text { D minor }\end{array}$ & 3 & BeRI 27 & $1746-47$ & 2 vn, va, b \\
\hline $\begin{array}{l}\text { 5. Symphony in } \\
\text { D major }\end{array}$ & 3 & BeRI 24 & $1746-47$ & 2 vn, va, b \\
\hline $\begin{array}{l}\text { 6. Symphony in } \\
\text { A major }\end{array}$ & 3 & BeRI 26 & $174^{6}-47$ & 2 vn, va, b \\
\hline $\begin{array}{l}\text { 7. Symphony in } \\
\text { B b major }\end{array}$ & 3 & BeRI 11 & $174^{6}-47$ & 2 vn, va, b \\
\hline $\begin{array}{l}\text { 8. Symphony in } \\
\text { F major }\end{array}$ & 3 & BeRI 17 & $1746-47$ & 2 vn, va, b \\
\hline $\begin{array}{l}\text { 9. Symphony in } \\
\text { C major }\end{array}$ & 4 & BeRI 13 & $174^{8-50}$ & 2 vn, va, b \\
\hline $\begin{array}{l}\text { 10. Symphony in } \\
G \text { major }\end{array}$ & 4 & BeRI 9 & $174^{8}-5^{\circ}$ & 2 vn, va, b \\
\hline $\begin{array}{l}\text { 11. Symphony in } \\
\text { D major }\end{array}$ & 4 & BeRI 14 & $174^{8-5^{0}}$ & 2 vn, va, b \\
\hline $\begin{array}{l}\text { 12. Symphony in } \\
G \text { major }\end{array}$ & 4 & BeRI 21 & $174^{8}-5^{0}$ & $o b, 2$ vn, va, b \\
\hline $\begin{array}{l}\text { 13. Symphony in } \\
\text { A major }\end{array}$ & 3 & BeRI 16 & $174^{8}-5^{0}$ & $2 \mathrm{fl}, 2 \mathrm{vn}, \mathrm{va}, \mathrm{b}$ \\
\hline $\begin{array}{l}\text { 14. Symphony in } \\
\mathrm{B} b \text { major }\end{array}$ & 4 & BeRI 29 & $174^{8}-5^{0}$ & $2 \mathrm{ob}, 2 \mathrm{vn}, \mathrm{va}, \mathrm{b}$ \\
\hline $\begin{array}{l}\text { 15. Symphony in } \\
\text { E minor }\end{array}$ & 4 & BeRI 22 & $174^{8-5^{\circ}}$ & $2 \mathrm{fl}, 2$ vn, va, b \\
\hline $\begin{array}{l}\text { 16. Symphony in } \\
\mathrm{D} \text { major }\end{array}$ & 4 & BeRI 23 & $174^{8-50}$ & 2 fl, 2 ob, 2 vn, va, b \\
\hline $\begin{array}{l}\text { 17. Symphony in } \\
\text { G minor }\end{array}$ & 4 & BeRI 30 & $1749-5^{2}$ & $2 \mathrm{ob}, 2 \mathrm{hn}, 2 \mathrm{vn}, \mathrm{va}, \mathrm{b}$ \\
\hline $\begin{array}{l}\text { 18. Symphony in } \\
\text { D major }\end{array}$ & 3 & BeRI 12 & $1749-5^{2}$ & $2 \mathrm{fl}, 2 \mathrm{hn}, 2 \mathrm{vn}, \mathrm{va}, \mathrm{b}$ \\
\hline $\begin{array}{l}\text { 19. Symphony in } \\
G \text { major }\end{array}$ & 3 & BeRI 19 & $1749-5^{2}$ & $2 \mathrm{ob}, 2 \mathrm{hn}, 2 \mathrm{vn}, \mathrm{va}, \mathrm{b}$ \\
\hline
\end{tabular}


Admittedly, this entire discussion has been based primarily upon several assumptions. First, that Roman's works were the products of a composer trained in the high Baroque style who made some effort to modernize himself in the face of the emergence of the new style now collectively called Classical. This implies that stylistic changes occurred as the result of a certain series of experiments on Roman's part, based upon his study of this style. Second, there is the assumption that Roman, whose main interest during the later period in his life was the adaptability of sacred music to the Swedish language, nonetheless found an opportunity-and perhaps a competitive impulse - to write concert pieces of this sort. Third, that Roman's sense of instrumentation and the forces available to him can be used as a determinant of chronological development. And finally, that he was himself interested in the creation of a new genre during this time of fluid generic nomenclature, and that he regarded the writing of symphonies as his own particular contribution toward making Swedish music current with continental trends.

The evidence for this type of chronological organization remains highly circumstantial-Bengtsson's general period of $1737-5^{2}$ still remains a likely overall timespan. Nonetheless, there does exist some evidence to support the assumptions. First, there is little evidence to suggest that Roman's music was influenced directly by the more lyrical melodic style prior to his visit to Italy in $173^{6-37}$, and therefore one might expect music to be written more akin to his early models, Pepusch and Handel. The various overtures all exhibit parallels particularly with Handel's mixed Baroque style; the slow, dotted rhythms of the introductions and the intricate linear counterpoint of the following fast movements. Second, after his visit to the Continent, he would hardly have been unaware of the emerging new genre, although the symphony itself took the better part of a decade (1735-45) to become established. Here too one finds that certain Roman works exhibit mixed stylistic traits that show the coalescence of the various Baroque styles and multi-movement forms into a single identifiable genre. Third, the idea of direct competition with a highly secularized and proficient ensemble, which might have served as an impetus for the writing of symphonies, exists in the apparent creation of parallel public concert series in Stockholm, beginning in 1743. When Adolph Frederik arrived in Sweden, he brought with him his own orchestra that had been trained on the continent and had likely been updated with the addition of independent horns and winds. Since the official Hovkapell of Frederik I, for which evidence exists of a sort of laissezfaire neglect, and the Ducal Kapelle were not merged, Roman, even though semi-retired, nonetheless had the need to establish some sort 
of competitive currency in the former. Again, there is evidence that, whenever Roman was in Stockholm, the Hovkapell seemed to undergo a period of revival, while during his absence the state of disrepair returned. While this may seem unfair to Roman's pupil, friend, and successor, Per Brant, the documents of the period show that Brant failed to wield the power or respect that Roman did. Finally, there is the evidence that Roman's patron, Adam Horn, himself developed over the years a small local ensemble at Fogelvik, which would have offered Roman yet another opportunity to write occasional works, such as symphonies.

While the speculative state of the evidence precludes a definitive dating of Roman's symphonies, the clear stylistic progression from the high Baroque Handelian style to the more homophonic, thickly textured galant style of the middle of the century indicates that these works represent a sense of progressive development. The composer, like his colleague Telemann, was interested in keeping up to date, and yet his own experimentation in the genre produced works that were both unique and singular. These works show a mature composer who is unafraid to develop a new, untried genre even though his own interests may have been in another field, vocal music. Further, despite increasing competition by newcomers, better versed in the new style, Roman was able to endow his efforts with greater concentration or ingenuity than theirs, thus becoming Sweden's leading composer of the early symphony and one of the principal figures of the galant style elsewhere in Europe. 